\title{
The City and Its Ways of Life: Local Influences on Middle-Income Milieus in Nairobi
}

\author{
Florian Stoll
}

\begin{abstract}
How is it possible to study the 'cityness' of cities, their particular character and the locally specific actions of their residents? One crucial aspect that distinguishes cities from one another is how social phenomena are embedded in a particular city's built environment, its economy, and particular horizons of meanings.

To analyse a significant example of this embeddedness, this chapter examines Kenya's Nairobi through the lens of social milieus in the middle-income stratum, the so-called 'middle classes.' ${ }^{1}$ Moreover, the milieu concept enables the identification of social groups that share sociocultural features such as specific ways of life, professional and leisure activities, and forms of consumption and investment. The text studies which local aspects are significant for milieus in Nairobi in comparison to Mombasa and other Kenyan cities. And using two case studies, the Christian Religious Milieu and the milieu of the Young Professionals, it illustrates how the particular city modifies these milieus.

Such an approach not only allows for a better understanding of the 'middle classes' in African cities as comprised of different identifiable milieus, it also yields a method for analysing the local particularities of a city, whether in Africa or other parts of the world. The chapter is significant for policy and practice because it introduces with the concept of social milieus a nuanced alternative to (middle) class approaches that distinguishes lifestyles, aims in life and forms of consumption. Also, the chapter discusses, using the example of Nairobi, how milieus are bound to specific structures of a city and might offer - from the perspective of basic research—suggestions for practical use.
\end{abstract}

1 Parts of this text refer to the working paper How to be Middle Class in Nairobi (Stoll, 2018). The sections that overlap are indicated by references at the beginning of the section.

(C) FLORIAN STOLL, 2018 | DOI:10.1163/9789004387942_013

This is an open access chapter distributed under the terms of the prevailing CC-BY-NC License at the time of publication. 
How to spot a Nairobian:

You should see Nairobians leaving the City. Once past Ruiru or the Great Wall, ${ }^{2}$ it is all systems go. Ask any "ocha" ${ }^{3}$ dude or dudette about Nairobi dressing and they will probably tell you girls wear hot pants and the boys are forever in vests and shorts and that clothing is never complete without an alcoholic drink in hand.

We are never like that here. The girls are always struggling to walk in heels and the dudes with their protruding bellies are always testing the limits of buttons. [...]

We are not loud, no, not when we are looking for money to go splurge in some other "ocha" county and show others how well we are living. When someone lands in Nairobi for the first time, expecting the good life, they are met by a people who are always in a hurry and very unfriendly.

Someone will collapse on the streets and people will give him bad looks, like how dare he fall in front of us, can't he go somewhere deserted and fall there?

'HOW то Spot A NaIrobian', Philip Mwaniki in Daily Nation, 3.10.2014

\section{1 \\ Introduction}

Some of the most iconic images of cities come from classical songs. Frank Sinatra sings about New York as the city that never sleeps; Dean Martin makes 'Volare' (to fly) a unique experience of Rome; Andre Filho honoured Rio de Janeiro as the 'Cidade Maravilhosa' (wonderful city) and contributed thus to its myth as a place for all kind of pleasures. These and many other songs construct vivid images of what it means to participate in the life of a particular city. Likewise, it is a matter of common knowledge that Lagos is very different from Cape Town and that the inhabitants of both cities vary in their everyday life routines. Looking at residents of Nairobi, there are also local particularitiesbut why is this the case? And how is it possible to go beyond stating merely differences and to study, instead, the 'cityness' of cities, including their characteristic features and the specific actions of their residents? This text contributes to a conceptual discussion about the urban in Africa and is, therefore, more than a case study.

2 Ruiru and 'the Great Wall' are both districts on the outskirts of Nairobi.

3 'Ocha' is a common expression in the Nairobi slang, Sheng, and refers to a rural area or someone's rural home. 
The starting point for this chapter are two developments that have taken place in many parts of Africa over recent decades and that overlap to a high degree. The first development is the increasing significance of cities and a tendency towards urbanisation. The second aspect is the rise of millions of families out of poverty as a result of economic growth. In the shadow of debates on 'Africa Rising' and 'Lions on the Move' (McKinsey, 2010), the middle-income group was coined in a rather popularising manner as 'the African middle-class' (AfDB, 2011; Ncube and Lufumpa, 2015). ${ }^{4}$ Such research focused on quantitative income and consumption rates but resulted in a poorly defined concept of economic class. In spite of the substantial critique of the use of the middleclass concept in Africa (Lentz, 2015; Melber, 2016; Darbon and Toulabour, 2013), there are few alternatives for studying middle-income strata. ${ }^{5}$ The majority of contributions are either ethnographic case studies of micro-groups (Spronk, 2012; Budniok and Noll, 2016) or large-scale quantitative studies on 'middle classes' that primarily look at the national level (AfDB, 2011).

Therefore, the starting point of this chapter is the large-scale critique of the debate on 'middle classes' in Africa that the author developed in several, partly co-authored publications (Neubert and Stoll, 2015; Daniel et al., 2016; Stoll, 2018; Neubert and Stoll, 2018). Transferring the term 'middle class' from the Euro-American context to Africa suggests that individuals in these income groups have sociocultural attributes such as typical values but also a financially stable position. While these attributes are considered essential characteristics of the 'middle class' in Europe and North America, they are often missing in the African middle-income strata. In contrast to the widespread characterisation of individuals with a daily consumption rate over the poverty level as 'the African middle-class' (AfDB, 2011), this text uses the terms 'middle-income strata' and 'middle strata', which are more precise characterisations than the well-established but weakly defined 'middle classes' in the social sciences.

4 The definition of the African Development Bank (AfDB) considers individuals with an average income of between two and twenty US dollars per day as 'middle class', with the stratum between two and four US dollars as an insecure floating class. Like other quantitative definitions of 'middle class' (see Neubert and Stoll, 2018), this economic range gives an orientation of who is neither poor nor rich. However, this text aims to elaborate qualitative aspects of diversity and the local embeddedness of middle-income strata and will therefore not discuss margins of economic definitions.

5 An exception is the concept of 'moderate prosperity groups' proposed by Andrianampiarivo (2016), who develops a multidimensional approach referenced by Darbon and Toulabour (2013) for middle-income strata. An interesting case study with the potential for a conceptualisation of middle-income groups is Claire Mercer's (2014) study on different types of living rooms in Tanzania. 
As an alternative to class, we have also introduced the milieu approach developed by German sociologists since the 1980s (Keim, 1979; Hradil, 1987; Grathoff, 1989; Schulze, 1993; Vester et al., 2001). The study of milieu allows us to distinguish meso-groups according to their particular priorities in life, such as ties to the rural and ethnic community, individual advancement, or religion (Neubert and Stoll, 2015; Stoll, 2016). The argument is that there is not one homogenous African or even Kenyan 'middle class' but that it is necessary, instead, to consider socio-culturally differentiated middle-income strata that are to a high degree locally embedded. As the chapter demonstrates using the example of Nairobi and other Kenyan cities, there are local differences in the composition of the milieus that can be linked systematically to a city.

The author will not only use milieu studies to provide a more nuanced picture of social groups and lifestyles in urban Kenya but will also investigate how these milieus are locally embedded in a particular setting and demonstrate how milieu studies also offer the possibility to consider particularities of a specific city. Comparisons are very helpful to identify general and unique local aspects of milieus and cities. We have considered in our research Nairobi and Mombasa, and to a lesser degree other Kenyan cities. This text focuses, however, on Nairobi and takes references to other cities only as points of comparison.

Recently, Jennifer Robinson (2006) made a major statement with regard to the study of urban African contexts when she claimed that it is necessary to treat them as ordinary cities and not just as the underdeveloped other of EuroAmerican urban settings. Robinson criticises the hegemonic developmental view in Urban Studies because it suggests the existence of a shared quality of African urbanity, without or even against empirical proof. She emphasises that it is crucial to investigate the local conditions of African contexts, instead of making assumptions based on an untenable theory. As such, Robinson set a new standard in the study of the urban in Africa by stressing that it is necessary to research cities on the continent in a similar way as anywhere else in the world. Robinson's approach thus encourages a localised approach, for it would be problematic to assume that the same or very similar 'classes' or milieus exist in African cities as many stratification theories tacitly assume for European states (e.g. Vester et al., 2001, for Germany).

Similar to language, which is always highly localised through dialects, slang and typical phrases, other aspects of social life are also bound to the economic, symbolic, political and historical environment of a city. The literature on Nairobi and other Kenyan cities shows how elements of the environment determine the lifestyles of members of specific milieus or the city in general. For instance, one volume (Charton-Bigot and Rodriguez-Torres, 2010) gives insights into different aspects of life in Nairobi, such as public politics, group identities, 
and spatial structures. Other research focuses on Young Professionals and their sex lives (Spronk, 2012), elite clubs (Connan, 2015) or the local dialect Sheng (Beck, 2015). Similarly, research on Mombasa has sought to establish the elements that influence city life using the methodology of the distinctiveness of cities (Berking, 2012).

A further strand of research emerged in the last decade (for an overview see Parnell and Pieterse, 2016; Ricci, 2016, 11-16; Werthmann, 2014) and conceptualises cities in Africa beyond isolated case studies. Authors from this field of study oppose the dominant negative characterisations of urban African contexts, which focus on supposed 'deficits' or the lack of order. Such attributes focus mostly on the weak organisation or bad performance of cities (Ricci, 2016, $13 \mathrm{f}$.). The author of this chapter also aims at developing an understanding of the urban in Africa that describes and analyses cities on the continent through empirical research and not as 'negative' or deficient in comparison to models of Northern cities.

Therefore, this chapter provides a case study with the milieu approach, which clarifies how local particularities modify group structures and interact with the space of the city. The highly diverse local precolonial, colonial, and postcolonial influences make it necessary to think of urban Africa in the plural, in a similar way as we differentiate contexts in Europe, the Americas and Asia. Accordingly, the composition of middle-income strata differs significantly due to local influences. Firstly, this chapter discusses why it is thus useful to examine milieus in the middle-income stratum and not 'middle classes'. Secondly, it provides an overview of the methodology of the research and the data. Thirdly, the chapter discusses Nairobi's 'middle strata' in the context of the city. For a better understanding, the text zooms in on the milieus of the Christian Religious and Young Professionals as case studies.

\section{Why Milieus and not 'Middle Classes'}

Other publications by the author have criticised the use of the concept of middle class in Kenya and other African countries because this approach does not consider the diversity of sociocultural groups in the middle-income stratum (Neubert and Stoll, 2015; Stoll, 2016; Stoll, 2017; Neubert and Stoll, 2018). This chapter adds a related critique that studies how the differentiation of social groups is bound to a certain place and its particularities. Following this argument, this section introduces milieu study as an alternative to class and the next sections demonstrate how a conceptualisation of cities can improve research on milieus, describing two milieus in Nairobi. 
In contrast to class, milieu study builds on shared cultural orientations, structures of meaning and characteristics (for this chapter cf. Stoll, 2018, and Neubert and Stoll, 2018). Class concepts aggregate vertical groups that are supposed to have similar structural characteristics such as income, occupations and lifestyles. In contrast, the idea of milieu is to identify horizontally differentiated groups with similar values, actions and aims in life. Milieu does not presuppose similar income and occupations but focuses on sociocultural elements. Class, and more particularly 'middle class', evokes ideas of a stable future and the possibility of saving and consumption. It is not clear, however, if it is possible to describe African societies in general and urban Kenya in particular with a vertical concept like class. According to Dieter Neubert, class is not an adequate analytical tool to study social groups in Africa as influences such as ethnicity, economic relations to the extended family, and urban-rural ties transcend a vertical analysis (cf. Neubert, 2005, 182-189). Studies of vertical class structures with clearly separated poor-, middle-, and high-income households of nuclear families do not describe social relations in African societies convincingly. In many African countries, complex forms of urban-rural connections and ethnic differentiation exist, which do not necessarily overlap with socioeconomic boundaries. The class concept implies more than being part of a certain income stratum. Since Karl Marx, class has been described as a group in the same socioeconomic position that shares certain interests but also cultural characteristics such as values, typical habits, and political views. In particular, in English-speaking academia, the term 'class' is not only used for group definitions but also for economic strata without acknowledging the cultural implications of the class notion sufficiently. Moreover, the class concept is not a flexible approach to studying groups but is bound to a vertical analysis. It is appropriate to studying forms of stratification that focus on high, middle and low strata but has difficulties to include horizontal forms of differentiation. The conceptual limitations of class affect research that is committed to examining also different lifestyles and sociocultural factors. Famous studies such as Bourdieu's Distinction (1984) or Leela Fernandes' (2006) work on middle classes in India analyse also sociocultural aspects and lifestyles. However, they do not introduce an alternative conceptualisation that goes beyond vertical group analysis.

Due to conceptual flaws of class, German sociologists have, since the 1980s, begun to discuss alternatives. It had become more and more evident that an analysis of vertical classes is not sufficient to understand social structure and lifestyles in late capitalism. In European societies of the nineteenth and early twentieth centuries, socioeconomic positions, professions, and lifestyles mostly overlapped. However, since the 196os, the impacts of deindustrialisation, the 
rise of post-materialism and other developments such as the dissolution of previous forms of class solidarity have led to new lifestyles in Germany and other Western democracies. Therefore, German sociology developed new concepts to examine sociocultural groups that share values, aims in life and leisure activities. These aspects do not necessarily correlate with income levels or professions, as the class concept assumes. While these approaches are very common in German social sciences, they are unknown in international contexts and it is necessary to introduce them here. The milieu concept and the more flexible notion of Lebensstile (lifestyles) are the most common tools for sociocultural analysis (for an overview on milieus see Isenböck et al., 2014; Rebstein and Schnettler 2014; Neubert and Stoll, 2015, $11 \mathrm{ff}$;; for lifestyles see Otte and Rössel, 2012).

While Pierre Bourdieu's study of culture in Distinction (1984) has been important for this debate, milieu theorists refer to Bourdieu and other vertical approaches in very different ways. Michael Vester et al. (2001) see for Germany a strong connection between class and the realities of life. They assume that milieus correspond strongly with vertical differences in the same income stratum including structure, values or leisure activities. Other versions of milieu have a stronger empirical orientation and study sociocultural elements like attitudes or forms of leisure activities with a stronger horizontal than vertical conceptualisation (cf. Hradil, 1987; Schulze, 1993). Likewise, the development of the milieu concept is closely linked to social and market research, for instance by the SIGMA-Institute (cf. Ascheberg, 2006) and the sInUs-Institute (cf. Flaig et al., 1993; Sinus, 2015). All versions of milieu analysis mentioned here aim to study lifestyle groups of a significant size in a certain setting. While milieu perspectives include ethnographic descriptions, they generally focus on the meso-level of reconstructed groups who share crucial sets of characteristics. Consequently, the analysis is situated between city, society or nation-state as possible macro-level and the individual at the micro-level.

This text puts more general conceptions of milieu into dialogue with local particularities. Due to the focus on milieus and specific elements of Nairobi, the chapter does not discuss the conceptualisation of cities and other elements of urban theory in detail. It is, however, possible to develop a more elaborated framework for the study of social milieus. Ash Amin and Nigel Thrift stress, in Seeing Like a City (2016), that cities consist of multiple networks, from everyday routines to politics and the economy, and thus assume a particular shape. Daniel A. Bell and Avner de-Shalit (2011) discuss the particularities of different cities under conditions of accelerated global connections in The Spirit of Cities. Why the Identity of a City Matters in a Global Age. A recent systematic approach is also offered, for instance, with the distinctiveness of cities/Eigenlogik 
der Städte (Berking, 2012; Löw, 2012), ${ }^{6}$ which studies how an understanding of the everyday knowledge and locally specific structures of meaning by residents can explain differences between urban settings. This research programme focuses on the question of how a city influences the ways of thinking, acting, and grouping that are crucial to the life of its inhabitants. Other works that study 'the cityness' of cities include Ulf Hannerz's Exploring the City (1980) or Janet Abu-Lughod's New York, Chicago, Los Angeles (1999). As the disputably most important theory of space and urbanity, it is also possible to consider cities as multidimensional constructs in the line of Henri Lefebvre's The Production of Space (1991 [1974]). In particular, Christian Schmid's (2005) interpretation of Lefebvre contextualises and clarifies the framework in such a way that it becomes possible to study cities as socio-spatial conglomerates. Another, already classic work is Doreen Massey's (2005) For Space, which develops a dynamic approach to space and place because she considers the concepts in a relational understanding as the outcome of contextual influences ranging from global impacts to economic policies and particular local forms of meaning making.

This study applies a descriptive version of the milieu concept that does not presuppose a vertical stratification (Hradil, 1987; Sinus, 2015). 'Descriptive' means the reconstruction of milieus results from empirical research, instead of deducing it from theory. The advantage of such an empirical focus is that it can integrate African, Kenyan, and specific local characteristics such as the importance of the extended family or religion for certain milieus.

\section{$3 \quad$ Methodology and Data}

The data was gathered mostly during nine months of fieldwork by the author in Nairobi and Mombasa. During five field stays between 2013 and 2016, the author conducted observations in significant places such as churches, restaurants and private homes, and carried out 97 biographical interviews in both cities. This data collection aimed at identifying groups with distinctive sociocultural orientations in life: social milieus. The research followed a contrastive approach that aims at differentiating milieus with distinctive traits. For this purpose, the study began examining publicly visible groups and contrasted them with a revised multilayered matrix developed by the sinus-Institut

6 There are two English translations for the German Eigenlogik der Städte. While 'distinctive logic of cities' (Löw, 2012) emphasises the emergence of phenomena from a particular setting, the other translation, 'distinctiveness' (Berking, 2012), stresses rather the particular character of a city. 
that covers the most significant areas of life (Flaig et al., 1993, 71; Neubert and Stoll, 2015, $8 \mathrm{ff}$.): demography/social position, space and places, aims in life, work/performance, ideals and role models, image of society, family/partnership, leisure/communication and everyday aesthetics. In the next steps, the research examined more difficult to access groups that spend, for example, most of their time in family circles or closed ethnic networks. Also, data from media reports or other studies (Spronk, 2012) contributed to constructing the milieus.

The methodology of this study considers milieus in the middle-stratum as particular to Nairobi and Mombasa. It also contrasts the differentiation of milieus to distinguish between identical and unique elements. The differences in size, density, heterogeneity of the population and city type are no obstacle for the comparison as they can be part of specific features of a city. With milieu studies, it is possible to interpret the particular ideas and actions of a milieu in relation to a city. In the case of the Young Professionals, these actions include visits to certain clubs wearing typical outfits. Thus, the milieu of the Young Professionals depends on an urbanised youth culture and club scene, which exists in Nairobi but not in Mombasa. It is important that the milieus have their starting point in the middle-income stratum but are not limited to it as sociocultural commonalities are the defining criterion.

The reconstruction of milieus and their particular local embeddedness methodologically builds on two combined analytical foci. Whereas both foci are in the research intertwined, an analytical separation clarifies the process of milieu generation. The first focus concentrates on the construction of milieus and uses field data to identify characteristics and elaborate milieus in Nairobi and Mombasa. The second focus combines these results with a study of Nairobi as a multidimensional space that influences the size and also certain characteristics of milieus. Such aspects range from the significance of clothes as markers of membership in a milieu to a particular career orientation that distinguishes Nairobi from Mombasa. Many other aspects such as job opportunities, the relation of religious communities or the proximity to the home areas of certain ethnic groups influence city structures and the composition of milieus as well. The description of milieus presents the results in Sections 3 to 5 in a more readable way and not according to the foci of analysis.

Focus I opposes the widespread, mostly implicit assumption that there is a culturally uniform African or Kenyan 'middle class', an assumption that economic definitions seem to make when they ignore sociocultural influences (AfDB, 2011; for the critique see Neubert and Stoll, 2018). The study examines in the first focus to which degree groups of significant size differ in their orientations in life, values, and consumption habits. For highlighting differences, 
the research referred to the matrix mentioned earlier (Neubert and Stoll, 2015, $8 \mathrm{ff}$.). The data collection aimed at identifying milieus by sets of distinctive characteristics such as values, orientations and activities in comparison with other milieus. The process of milieu construction does not concentrate on local particularities, but it can also consider features and mechanisms that are unique to Nairobi or Mombasa, locally adapted to a city, or identical in both cities.

Focus II links the empirical data on milieus from Focus I systematically to particularities of Nairobi and Mombasa. This part examines how milieus relate to existing structures of a city and adds more information from historical and other sources that explain continuities and new developments. The study examines characteristics such as typical beliefs and practices but also the demarcation lines between milieus. Also, this part considers historical influences and events in a diachronic perspective that is still significant today. In the best case, it would be possible to identify routinised patterns as the outcome of historical paths. For instance, the emergence of a new urbanised part of Nairobi's middle stratum during the last two decades resulted from the growth of the city, the emergence of a new generation of urban-born Kenyans, and new opportunities for migrants from other cities.

\section{$4 \quad$ Middle-Income Milieus in Nairobi}

Nairobi is Kenya's economic centre, the seat of the national government and the preferred destination for work migration (for this chapter cf. Stoll, 2018). The city is a place for all kinds of industrial labour, trade and businesses of different sizes. It hosts several universities and government institutions that attract many ambitious young people. Nairobi is also home to thousands of international companies and non-governmental organisations that offer wellpaid jobs in internationally connected fields. With more than three million inhabitants, the city is by far Kenya's biggest urban agglomeration. Nairobi is a classic example of the rapid growth of an African city that lacked sufficient industrialisation to include the rising number of rural migrants. The Metropolitan region constantly grew from its beginnings as a small settlement in 1900 , counting 510,000 inhabitants in the year 1970 and 1.35 million in 1980 . Even though official statistics vary, the city may at present have a population of more than three million, and between 4.5 million (UN-Habitat, 2016) and six million (Amis, 2006, 173; Kenya National Bureau of Statistics, 2009) may live in the Metropolitan area. While statistics are unreliable, international organisations estimate that up to 60 percent of the city's population live in slums 
(UN-Habitat, 2013) and that about half of its residents are poor (Oxfam, 2009; UN-Habitat, 2013). This also means that a considerable share of its population lives above the poverty line, with around one-third in the middle-income stratum.

For decades, migrants from all parts of Kenya lived in Nairobi as 'Peasants in Cities' (Mangin, 1970). People earned money in urban occupations and reinvested in their rural home areas. Today, this is no longer the dominant mode of living but one of many possibilities. In the last two decades, a generation of 'middle class' Nairobians emerged with different basic orientations in life. For instance, some members of this middle stratum have a highly urban and others a stronger rural focus. The only feature that they share is a similar income above the poverty line. These economic opportunities leave space for different forms of consumption, according to specific priorities in life.

While not everyone in the statistical middle-income stratum has sufficient means to purchase costly goods, consumption and investment preferences show central orientations of milieus. Some members of the 'middle class' prefer to buy land in the countryside, whereas others invest in business activities and again others prefer to buy stylish clothes and smartphones. Members of the middle-income stratum differ in their lifestyles, which include values, future orientations, and many other aspects. It is crucial, nevertheless, to consider all milieus as part of contemporary, modern Nairobi. In particular, a common distinction between modern and traditional is misleading because all milieus are in many ways modern as their members use digital communication, participate in global discussions and are highly mobile.

Through empirical fieldwork, Dieter Neubert and the author have identified six milieus in Nairobi (cf. Neubert and Stoll, 2015, 8; see also graphic 1):

- Neo-traditionals ${ }^{7}$ have close ties with members of their extended family and their rural and ethnic community. This includes a strong emotional bond but also sharing of finances. Also, members of this milieu often take political positions that favour their ethnic group.

- Social Climbers focus on saving to advance individually and to improve the situation of their nuclear family. Many of them work long hours and save a high percentage of their income for investing in a business or for studying.

7 It is crucial that there is no distinction between more or less modern or traditional milieus. We call this milieu 'Neo-traditionalists' as they refer in a particular way to traditions. This does not mean that these traditions have existed for a very long time. The crucial point is the subjective orientation towards such values and their significance for the conduct of life in this milieu. 
- Members of the Stability-Oriented Pragmatic milieu try to maintain their current position and have fewer aspirations than members of other milieus. This includes moderate consumption with their family with whom they spend most of their time out of work at home.

- Characteristics of the Cosmopolitan-Liberal milieu are a clear stance for civil values and against corruption and tribalism, combined with career ambitions. Members of this milieu often work in non-government organisations and are active in human rights or environmental groups.

- Members of the Christian milieu (also Christian Religious) regularly participate in church-related activities and spend a large part of their leisure time away from their families with other parish members. Their orientation in life focuses on religion, the church, and economic success.

- Young Professionals are between 20 and 35 years old and come mostly from privileged families in upper or upper-middle strata. They combine hedonistic consumption, an international orientation and career ambition in economically well-paid fields.

In addition to the listed milieus, there are also Muslim and Hindu micromilieus in Nairobi for which there are not sufficient data. These micro-milieus are, however, considerably smaller than the Christian Milieu. The Young Professionals and the Cosmopolitan Liberals are limited to Nairobi and do not exist as milieus of a significant size in other Kenyan cities.

The composition of milieus in Mombasa's middle-income stratum differs significantly due to economic, cultural and other factors. Mombasa is Kenya's access point to the Indian Ocean and also a hotspot for global tourism. It is a port city with a long history of overseas trade to the Middle East and to India, and a large Muslim community. There are divisive lines between Muslims and Christians that overlap often with ethnicity. Members of ethnic groups such as the Swahili and Michikenda have been in Mombasa for generations; they are Muslims and are also bound by lifestyles to Mombasa's old town. In contrast, members of other ethnic groups such as Kikuyu or Luo are mostly Christian migrants to Mombasa of the first or second generation. These migrants usually come for work at touristic spots or the port.

There are partly different milieus in Mombasa's middle-income stratum but also the size of certain milieus varies. In contrast to Nairobi, there is a Swahili milieu with a distinctive lifestyle that is limited to Mombasa. The Christian Milieu is considerably smaller and there is no milieu of Young Professionals because Mombasa has neither the professional opportunities nor the club scene and cultural life that attracts the ambitious members of this milieu.

Figure 1 visualises the milieus in Nairobi. The size of the bubbles does not represent the actual size of milieus as there is not sufficient data. There is also 


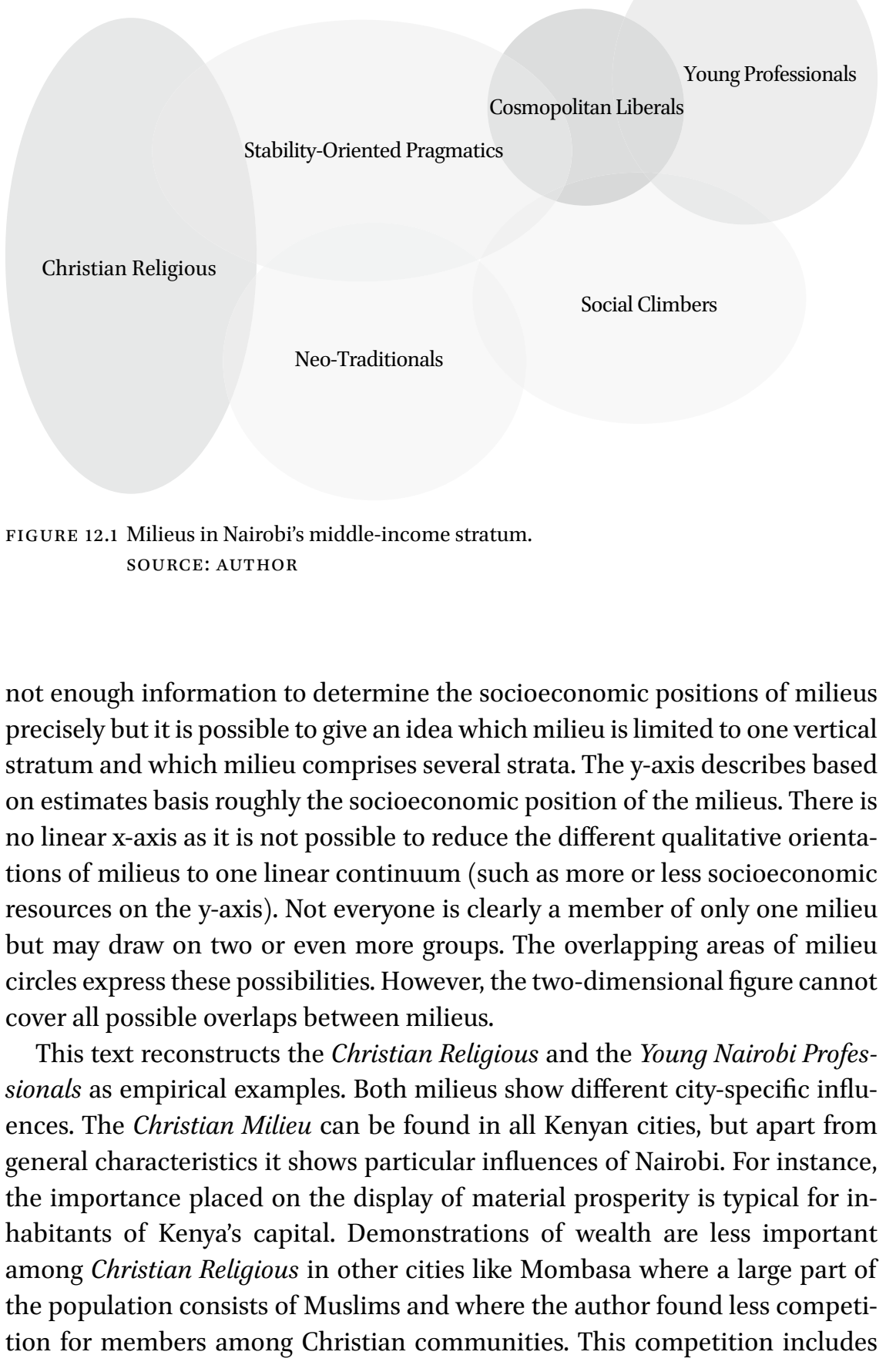


spiritual programmes but also the promise of material wealth as the next section on the Christian Religious Milieu demonstrates.

This section describes first general characteristics that the Christian Milieu (also Christian Religious) (cf. Stoll, 2018) in Nairobi, Mombasa and Eldoret share (Niechoj, 2016). The second part elaborates which features are unique to Nairobi and how they are related to the city's distinctive character. Being religious is part of almost every Kenyan's self-definition, and only a tiny minority do not consider themselves as part of a Christian, Muslim or other community. Religion and church activities have, therefore, a high significance in the social and symbolic order of Kenya. It is, however, crucial to remember that this section does not study religious groups such as Pentecostals or Catholics but describes individuals with a similar lifestyle that differs from the lifestyles among other milieus. Moreover, the case study is limited to the Christian Milieu, as the author does not have enough data on Muslim or Hindu groups in Nairobi to make reliable categorisations.

In contrast to many Kenyans who would call themselves Christians, members of this milieu are more dedicated to their church and follow religious rules in a more consequent way (cf. Neubert and Stoll, 2015, 11f.; Stoll, 2018). Christian Religious are active in their church community and engage in several meetings per week, such as Bible study, the counselling of troubled church members and service-based worship. Apart from with their families, members of this milieu spend a large share of their leisure time in religious networks and often have close friends in church. Frequently, work or business are intertwined with religion. Another distinctive trait is that members of this milieu follow norms of their community with greater consequence than less dedicated Christians. For example, members of the Christian Milieu distance themselves in interviews from premarital sex and say they avoid places that sell alcohol. Another characteristic is that they regularly pay the tithe, ten percent of their income, to their parish. The foundation for their actions is - in contrast to the Neotraditional milieu for example - the Bible and not the values of their ethnic community. In spite of the existence of connections to the extended family in the countryside, these ties are not the main orientation in the life of Christian Religious.

By their religious convictions, most members of this milieu have strong career ambitions. Economic success is, unlike in the majority of European Christian denominations, not interpreted as materialism or a lack of spirituality. Rather, it is common in many Kenyan churches to display financial well-being 
by wearing expensive clothes, driving prestigious-brand cars and donating to the community. All of these actions can raise a church member's status. In spite of differences between Christian groups in Kenya, the milieu analysis focuses on the commonalities in the lifestyle of committed church membersas they are distinct from members of other described milieus.

The previous part elaborated general elements of Christian Religious that are common in Nairobi, Mombasa, Kisumu and Eldoret. The next sections give examples of unique influences in Nairobi. Information from interviews and observation shows that the ambition and the business focus of many Christian Religious are on the average more intense-or, in the language of many Nairobians, 'more aggressive', with a positive connotation - than those of their counterparts in other Kenyan cities. This will to obtain economic success is a local meaning structure that is also very strong in most other middle-income milieus in Nairobi. Individuals perceive Nairobi as a place that offers economic opportunities and a good environment for life but is also competitive and expensive. The city attracts individuals from all parts of Kenya and East Africa with its promise of social advancement by economic success and the opportunity to study at a university. Residents of Nairobi and Mombasa perceive Kenya's capital as much faster and higher paced than Mombasa, which people in both towns describe as a relaxed beach town.

Correspondingly, expectations of prosperity are essential parts of church programmes and are more important than in Mombasa. Many churches in Nairobi are strongly affected by the competitive atmosphere of the city as they are often much bigger than the churches in other cities and they try, with very particular programmes, to attract new members. Another aspect is the comparatively higher acceptance of changing one's church affiliation as a life reform in Nairobi. A number of churches offer not only spiritual guidance but a life plan for social advancement, although this is especially true of Pentecostal churches (for Pentecostalism in Nairobi see Droz, 2010). This focus on success is particularly visible in some Pentecostal communities in Nairobi, communities whose idea systems combine an intense spiritual programme with an appreciation of personal development and economic improvement. These Pentecostals, and to a lesser degree many other communities, interpret professional success as an expression of God's favour. In some big churches, pastors even ask their congregants to be dressed well, and in this way exclude poor people from attending. ${ }^{8}$ Some pastors receive so many donations from church members that they build mansions and buy private jets.

8 There is a debate about the head of the Jubilee Christian Church Parklands, reverend Kathy Kiuna, who has made comments about dressing and the economic status of church members. 
Obviously, individuals in Nairobi are expected not only to be successful but also to show this in a particular way. While members of church programmes for individual advancement do not always succeed in improving economically, they are, nevertheless, supposed to demonstrate status by good looks, highbrand cars and huge donations. In certain churches, showing one's good situation can even overcome the moral boundaries of sexual restrictions; at Sunday services, young women wear short skirts to display, by their good looks, their elevated social position. Such a proof of God's favour would not be acceptable in many churches, especially in other cities. Here, the emphasis on prosperity has become stronger than the control of sexuality. With their entanglement of faith and success orientation, these churches are bound to Nairobi: it is a locally embedded norm in Nairobi to demonstrate status through appearance, exclusive clothing, and conspicuous consumption. The Sunday services of many church communities in Nairobi are known as catwalks with a spiritual background, for instance in Parklands, Westlands or Kilimani. Such visual displays of well-being also have the aim of illustrating the dominance of Christians in Kenya's capital. Another important aspect is that many churches in Nairobi demand considerable donations. The contrast to Mombasa with its higher share of Muslims is a good point of comparison. For instance, in Mombasa clothes do not mark social differences to the same degree as they do in Nairobi. Also, interviews with members of church communities in Mombasa reveal that many of them do not feel as secure as their counterparts in Nairobi. In 2014, attacks by Al-Shabaab on churches in Mombasa produced considerable uneasiness among Christians. Additionally, witchcraft was a more frequently mentioned topic in interviews in Mombasa than in Nairobi.

One result returned by the research is that in Nairobi different areas of life frequently mix although they are rather separate in other cities. For instance, members of the Christian Religious Milieu in Nairobi frequently work in areas where they come into contact with behaviours that show little respect for central Christian norms. The consequences for life are illustrated by the example of Jennifer, a religious, 24-year-old student who sings not only in church but also as a professional backing singer for bands. Many situations in the music business are related to sex:

'Yeah, it's the popular music in Kenya is about that. Basically like [...], it's about party life and women, and all those things. [...] Yeah, 'cause you know being like a background vocalist, for some people they want to dictate what you'll wear, they want to dictate how you should dance on stage, they can even push you to dance with someone. I have seen it happening in concerts. [...] And that for me is something I really didn't look forward to being or doing, cause I really_-first impressions are everything. Yeah. So, I may, today you're maybe 
somebody's background vocalist, but tomorrow you may want a job in a good organisation. And maybe somebody saw you dancing in a, in an otherwise, not so proper manner with someone. And this happens to be a director of a company and he'd have problems hiring you. 'Cause he feels like you would change the company's imagination'. (Interview with Jennifer, 13.09.2013)

To earn money, Jennifer is often at places where she must interact with people who consume much alcohol and where casual sex is normal. She does not drink and emphasises in the quote above, that she does not want to dress provocatively or dance with men because concert organisers ask for it. However, Jennifer not only draws a moral boundary, she is also worried about spoiling her future employment prospects if someone sees her. Many members of the Christian Milieu in Nairobi face similar problems because they work in environments where drinking, partying and one-night stands are usual. In a similar way to the music scene, many companies in Nairobi have an after-work culture of going out together and celebrating until late into the night. Religious Christians such as Jennifer must develop particular strategies to deal with such situations. In comparison, despite large amounts of club life and prostitution in Mombasa, there seem to be fewer overlaps in the everyday situations of inhabitants in the coastal town, by and large. In Mombasa, clubs and places for prostitution are concentrated in parts of town such as Mtwapa and Nyali, which are far away from the homes and jobs of most inhabitants, including the Christian Milieu. Professional areas and clubs are socially and spatially more separated than in Nairobi, possibly also as a result of the connection to domestic and international tourism present in Mombasa.

Nairobi is the only city in Kenya where Young Professionals exist as a milieu of considerable size (cf. Stoll, 2018). The emergence of this milieu is no coincidence but is closely related to the city's special character as a national and regional economic and cultural hub for Kenya and even neighbouring countries. The milieu of the Young Professionals has taken shape in the last two decades and is an expression of new urbanisation processes that are significant for present day Nairobi. To many young adults, Nairobi promises individual success and a hedonistic urban life without subordination to the extended family or to ethnic or religious community. Young Professionals are between 20 and 35 years old and grew up mostly in middle-income or even rich families from Nairobi or other cities. Nevertheless, there are also members of this milieu from rural areas who migrated to Nairobi. As 'Young Nairobi Professionals' 
(Spronk, 2009, 501-emphasis added), this group of well-educated young employees, entrepreneurs or students (cf. Spronk, 2012) differ-mostly in their financial possibilities and their everyday lives—-strongly from the poor majority of the city.

The Young Professionals are often self-employed in areas with good financial returns such as finance, information technology or resource trading. They work in globally operating firms and institutions such as non-governmental organisations, the United Nations or multinational companies. Many of them travel regularly to Europe or North America. Young Professionals are famous for forms of conspicuous consumption, with colourful clothes, the newest electronic gadgets such as the latest phones, and partying in clubs and bars. Members of this milieu must have the financial means to pay for elegant clothes, for drinks in bars and clubs, and for restaurants in the city centre or districts like Westlands or Kilimani. Moreover, members of this milieu attend events such as the monthly 'Blankets and Wine' Festival, the 'Koroga' Festival, the Nairobi fashion market and shiny parties or art festivals. The role models of those in this milieu are successful business people and celebrities. In public, the lifestyle of Young Professionals sometimes clashes with the ideals of other milieus. As an example, since 2014 groups of men have attacked, on several occasions, women and tried to strip them naked in public places because they wore, in their opinion, too short skirts and acted in an immoral way.

Young Professionals have a weaker affiliation to rural and ethnic communities, and to their extended families, than members of most other milieus. A considerable number of them try to cut the ties to their extended families to escape social control and financial obligations. In this way, they distance themselves from the moral economy of rural villages and avoid forms of mutual solidarity.

Structural and cultural factors make Nairobi attractive for Young Professionals. The milieu is bound to the city because the well-paid jobs in international companies and non-governmental organisations are located here. Similarly, Nairobi has a uniquely vibrant nightlife. Style and looks are crucial for members of this milieu. They are the spearheading group of Nairobi's specific form of visual boundary-making by aesthetics. To be 'hip' in Nairobi it is not enough to merely have money for the latest style and mobile phone. It is crucial in this environment to also know what to wear, how, and when and where to wear it. Their well-paid jobs - but also money from their well-established families and from bank loans-give Young Professionals economic opportunities and allow them to display exclusive taste. This is a privileged situation that distinguishes them from the majority of Nairobi's young inhabitants. All these aspects produce symbolic economic and cultural boundaries (cf. Lamont, 1992, 4). High 
economic and cultural hurdles make it difficult for migrants from rural locations and for Nairobi's poor to become part of this milieu.

Rachel Spronk (2012) has written a comprehensive study of this milieu and its members' sex lives. According to Spronk, the rise of the Young Professionals is intertwined with the economic growth and the new job opportunities that have emerged since around 2000. She also shows how these young Nairobians maintain their gender-specific identities by going to popular places. Part of typical interactions is having certain types of relationships, including those that enable casual sex. In spite of possible conflicts with social conventions, sex has - for many yuppies - an important psychological and social function: 'Sex, which is central to self-expression, is somehow associated with "being modern", while at the same time it feels "natural". In their self-expression, their notions of self are "African", "non-Western", "nontraditional"' (Spronk, 2012, 14). This quote shows that sex can bridge, at least partly, the contradictions that young people feel as they become part of a globally integrated Kenya and when they fear they might lose connection to their African background.

Biographical data show how Nairobi's urban environment gives Zara, a 31-year-old business consultant and owner of a small travel booking company, freedom from the moral and monetary expectations of her family. She does not own a car or even a fridge, probably to hide her good financial situation from relatives. For instance, she not only goes to clubs and restaurants but also travels to lodges in the Masai Mara and to European countries. Her individualised lifestyle not only gives her financial opportunities, she can also hide her love life from her family and avoids questions about marriage and children. Although Zara does not mention it in the interview, she has-according to friends-successive and sometimes multiple boyfriends.

Another interviewee, Adrian, is a 27-year old graphic designer who grew up in Karen, one of Nairobi's best areas. He is a co-owner and co-director of a small marketing and event company, which he founded together with a friend three years before the interview. After attending expensive schools and securing a diploma as a graphic designer, he started working for a Chinese pay-TV company in Nairobi. With some years' work experience, he decided to bring his knowledge of photography, advertising and digital marketing to his own company. Adrian is well-dressed in colourful outfits or, if necessary, more formal business clothes. He wears his hair in well-kept dreadlocks, exercises several times a week at the gym and goes regularly to popular bars and festivals. As a graphic designer, he owns a MacBook and a digital camera with several lenses. Additionally, he often goes on holidays in various places in Kenya.

In contrast to members of other milieus, Young Professionals follow a generational, individualised lifestyle that focuses on hedonistic consumption and 
career, not on church-related activities as is the case for the Christian Milieu. Most Young Professionals leave this milieu or reduce, at least, their visits to bars and festivals before they reach 35 years of age. Usually, the reason is that they get married and have children.

This chapter has examined middle-income milieus (sociocultural groups with similar lifestyles) in Nairobi to demonstrate how such a conceptualisation can include specific local aspects. The milieu concept is an alternative to the popular but not very nuanced concept of the 'middle class' and considers the most significant aspects of life in order to construct social groups. Moreover, due to their focus on empirical findings, milieu studies are able to consider, likewise, particular aspects of a city, such as local subcultures, economic branches or particular forms of global connections.

By examining middle-income milieus and their relation to Nairobi as an example, the text contributes to the debate on cities in Africa. It has become widely accepted that it is necessary to study African cities as 'ordinary cities' (Robinson, 2006) and not as the 'other' of cities in the global North as developmental views suggested for a long time. Robinson (2006) stresses that we must approach each city as a particular constellation, and build on empirical research and not on untenable theory from 'EuroAmerica'. It is necessary to study cities in Africa without assumptions that have no empirical proof, such as underdevelopment as an alleged commonality of urban Africa. Similar to Robinson's claim, milieu theory demands we consider social groups according to local findings and study them, therefore, in forms other than vertical, economic strata or 'classes'. In particular, the concept of the 'middle class' has so many, often contradictory connotations that its transfer to Africa invites one to make assumptions before one has even begun to learn anything about the groups that lie between the poor and the rich. From a typical 'middle class' lifestyle to a financially stable situation and moderate political views, there are many attributes that are not necessarily found in the middle-income strata of African countries. Moreover, it is doubtful if vertical categorisations such as 'middle class' or 'working class' can grasp the most distinctive realities of life in twenty-first century Kenya and other African settings. Including sociocultural aspects in the process of group construction is, on the African continent, particularly important because many features such as ongoing urban-rural connections, the affiliation to the extended family but also the emergence of new urban lifestyles are frequent there but missing in class studies and Northern 
social theory in general. These aspects influence individuals' lives on a horizontal level that income distribution has difficulties analysing. In contrast to class, milieu refers to the most significant sociocultural characteristics and may offer an alternative. Also, due to their empirical perspective, milieu studies are open to local particularities and do not transfer the same model of stratification to each city in a certain country or region.

This chapter illustrates how the Christian Milieu and the milieu of Young Professionals are bound in specific ways to Nairobi. But what do these descriptions of milieus in the middle stratum tell us about Nairobi as a city? The Christian Milieu in Nairobi is different from its counterparts in other Kenyan cities in terms of its greater orientation to economic success and its degree of organisation. The Young Professionals exist as a milieu of significant size only in Nairobi, where many companies and non-governmental organisations, an entrepreneurial environment and a lively club scene attract young, well-educated Kenyans. In Kenya's capital they can follow their career paths and live a hedonistic, individualised lifestyle.

The text has portrayed Nairobi as an 'ordinary city', without deductive theoretical assumptions about a specific African urban quality — admittedly, from a particular sociological perspective with a focus on lifestyles, meanings and culture. Likewise, the study of middle-income milieus provides particular insights into aspects such as urbanism and urban-rural ties, which are crucial parts of most African cities but may manifest themselves there in ways very different to those found in Nairobi. A short discussion with a focus on urbanism and urban-rural ties demonstrates the usefulness of the milieu approach. As a result, the differentiation of milieus in the middle stratum results from Nairobi's unique form of urbanism.

For instance, the Young Professionals' highly individualised lifestyle cannot be explained merely by structural conditions such as the size of Nairobi or the job opportunities and good salaries. Rather, the cultural importance of entrepreneurial success and the material display of wealth provide the symbolic basis for the existence of the Young Professionals as a milieu. A strong entrepreneurial attitude and a tendency to display visible symbols of one's success are characteristic of many residents of Nairobi, also among the Christian Religious. Because the Young Professionals do not exist as a milieu in Mombasa and even members of the Christian Religious Milieu, by and large, do not show similar career ambitions in Mombasa, it is highly plausible to consider the strong orientation towards economic success and demonstrations of well-being as characteristics of Nairobi. For the inhabitants of most cities in sub-Saharan Africa, urban-rural ties are significant, but the way in which milieus relate to them is revealing with regard to specific forms of urban life. There are different ways in 
which residents of Nairobi relate to their extended families and the rural communities of the countryside. Young Professionals focus on their individual lives in the city, and they either have few connections to their extended family or even try to escape the financial obligations attached to kinship. For members of the Christian Religious Milieu, strong relations with the extended family and rural community are possible, but they are-mostly—less important for their lifestyle than the activities that take place in their church. In contrast, ties to the extended family and ethnic group in their rural home form a central part of life for another milieu, the Neo-traditionals. They share a considerable proportion of their income with relatives, and the development of their local communities is also crucial to them. Urban-rural ties are one significant aspect that all milieus deal with, but they do so in very different ways.

The milieu perspective demonstrates how urban-rural ties are enacted on the level of meso-groups in Nairobi and how this relates to their lifestyles. Furthermore, it is possible to study other significant aspects of African cities by a focused research into milieus, from economic practices to movement patterns, and the use of infrastructure in a wide sense that includes housing, education or forms of social security. Many new developments have deeply changed lives in African cities over the last two decades, and the milieu perspective may help us to study these. For instance, such different aspects as growing digitalisation and changing global-local relations, but also gender, affect individuals in specific ways according to their lifestyles. How and for which purpose do members of a milieu use smartphones, social media and messengers in a certain city? Which specific global influences affect members of which milieu in a certain city? From new Chinese economic activities to mass tourism, there are many aspects on the global level that change the realities of life on the local level. Nevertheless, field research is necessary to understand how global developments are being integrated into the routines of cities.

Further, gender relations are a very important topic that differs significantly across different cities. The milieu approach widens scope and allows one to study gender relations in certain groups and with respect to particular features of places. As an example, gender roles and related ideas differ strongly between the Christian Religious Milieu and among the Young Professionals in Nairobi. Relations to aspects such as sexuality and expectations with regard to women and men, but also attitudes towards homosexuality, differ strongly between these and other milieus. Finally, milieu studies can increase our understanding of certain cities for future comparative research. Also, comparing ways of life among middle-income milieus in selected African cities will reveal local particularities. Which milieus exist in Lagos and Cape Town, which similarities and differences are there in comparison to Nairobi, and how do these findings 
relate to the general characteristics of these cities? Furthermore, comparisons of milieus in different parts of the global South and North may provide new forms of knowledge - for example, with a focus on selected topics such as the use of digitalisation and gender. The milieu concept can be a fine bedfellow for the study of the urban. In Africa, but even elsewhere in the world.

\section{Acknowledgements}

I am grateful for the support of the German Ministry of Research for the project 'Middle Classes on the Rise', which was part of the Bayreuth Academy of Advanced African Studies, and for the support of the Volkswagen Foundation for a postdoc scholarship at the Center for Cultural Sociology, Yale University. The chapter was written in Bayreuth and at Yale. The team of the project 'Middle Classes on the Rise' has a sociological part (Dieter Neubert and Florian Stoll) and an anthropological part (Erdmute Alber, Lena Kroeker and Maike Voigt).

\section{References}

Abu-Lughod, J. (1999) New York, Chicago, Los Angeles. (Minneapolis, MN: University of Minnesota Press).

AfDB (African Development Bank) (2011) The Middle of the Pyramid: Dynamics of the Middle Class in Africa, Market Brief (Abidjan: AfDB), https://www.afdb.org/filead min/uploads/afdb/Documents/Publications/The\%2oMiddle\%20of\%2othe\%20 Pyramid_The\%20Middle\%20of\%2othe\%2oPyramid.pdf (accessed on 10 May 2018). Amin, A. and N. Thrift (2016) Seeing Like a City (Cambridge: Polity Press).

Amis, P. (2006) 'Urban Poverty in East Africa. Nairobi and Kampala's Comparative Trajectories', in D.F. Bryceson and D.H. Potts, (eds.) African Urban Economies. Viability, Vitality or Vitiation? (Basingstoke and New York: Palgrave Macmillan), pp. 169-183.

Andrianampiarivo, T. (2016) 'Moderate Prosperity: An Adaptation of the Middle Class Concept to a Malagasy Rural Area. The Case of Itasy', Review of Social Economy 75(1), pp. 26-48, DOI: 10.1080/00346764.2016.1171384.

Ascheberg, C. (2006) 'Milieuforschung und Transnationales Zielgruppenmarketing', Aus Politik und Zeitgeschichte, 44-45, pp. 18-25.

Beck, R.M. (2015) 'Sheng: An Urban Variety of Swahili in Kenya', in N. Nassenstein and A. Hollington (eds.) Global Repertoires and Urban Fluidity. Youth Languages in Africa, pp. 51-79.

Bell, D.A. and de-Shalit, A. (2011) The Spirit of Cities. Why the Identity of a City Matters in a Global Age (Princeton, NJ: Princeton University Press). 
Berking, H. (2012) 'The Distinctiveness of Cities: Outline of a Research Programme', Urban Research \& Practice, 5(3), pp. 316-324, DOI: 10.1080/17535069.2012.727549.

Bourdieu, P. (1984) Distinction. A Social Critique of the Judgement of Taste (Cambridge, MA: Harvard University Press).

Budniok, J. and A. Noll (2016) 'Konsum und Distinktion. Verortungen der ghanaischen Mittelklasse', in A. Daniel, S. Müller, F. Stoll and R. Öhlschläger (eds.) Mittelklassen, Mittelschichten oder Milieus in Afrika? Gesellschaften im Wandel, Politik und Gesellschaft in Afrika, 2 (Baden-Baden: Nomos), pp. 111-132.

Charton-Bigot, H. and Rodriguez-Torres, D. (eds.) (2010) Nairobi Today. The Paradox of a Fragmented City (Dar es Salam: Mkuki na Nyota Publishers).

Connan, D. (2015) The Decolonization of Private Members Clubs Socialization, Respectability and Elite Formation in Modern Kenya. Unpublished dissertation.

Daniel, A., S. Müller, F. Stoll and R. Öhlschläger (eds.) (2016) Mittelklassen, Mittelschichten oder Milieus in Afrika? Gesellschaften im Wandel, Politik und Gesellschaft in Afrika, 2 (Baden-Baden: Nomos Verlagsgesellschaft).

Darbon, D. and C. Toulabour (2013) Quelle(s) Classe(s) Moyenne(s) en Afrique? Une Revue de Littérature, Document de travail, 118 (Paris: Agence Française de Développement).

Droz, Y. (2010) 'Pentecostalism in Nairobi', in H. Charton-Bigot and D. Rodriguez-Torres (eds.) (2010) Nairobi Today. The Paradox of a Fragmented City (Dar es Salam: Mkuki na Nyota Publishers).

Fernandes, L. (2006) India's New Middle Class: Democratic Politics in an Era of Economic Reform (Minneapolis: University of Minnesota Press).

Flaig, B.B., T. Meyer and J. Ueltzhöffer (1993) Alltagsästhetik und politische Kultur. Zur ästhetischen Dimension politischer Bildung und politischer Kommunikation (Bonn: Dietz).

Grathoff, R. (1989) Milieu und Lebenswelt (Frankfurt am Main: Suhrkamp).

Hannerz, U. (1980) Exploring the City. Inquiries Towards an Urban Anthropology (New York: Columbia University Press).

Hradil, S. (1987) Sozialstrukturanalyse in einer fortgeschrittenen Gesellschaft. Von Klassen und Schichten zu Lagen und Milieus (Opladen: Leske + Budrich).

Isenböck, P., L. Nell and J. Renn (eds.) (2014) Die Form des Milieus. Zum Verhältnis von gesellschaftlicher Differenzierung und Formen der Vergemeinschaftung, Zeitschrift für theoretische Soziologie, Sonderband 1 (Weinheim: Beltz Juventa).

Keim, K.-D. (1979) Milieu in der Stadt. Ein Konzept zur Analyse älterer Wohnquartiere (Stuttgart: Kohlhammer).

Kenya National Bureau of Statistics (2009) 2009 Kenya Population and Housing Census Analytical Reports, https://www.knbs.or.ke/2009-kenya-population-and-housing -census-analytical-reports/ (accessed 1 November 2017). 
Lamont, M. (1992) Money, Morals, and Manners. The Culture of the French and American Upper-Middle Class (Chicago: University of Chicago Press).

Lefebvre, H. (1991 [1974]) The Production of Space (New York: John Wiley \& Sons).

Lentz, C. (2015) Elites or Middle Classes? Lessons from Transnational Research for the Study of Social Stratification in Africa, Working Paper of the Department of Anthropology and African Studies, 161 (Mainz: Institut für Ethnologie und Afrikastudien, Johannes Gutenberg Universität), http://www.ifeas.uni-mainz.de/Dateien/AP_161 .pdf (accessed on 1 September 2017).

Löw, M. (2012) 'The Intrinsic Logic of Cities: Towards a new theory on urbanism' Urban Research \& Practice, 5(3), pp. 303-315, DOI: 10.1080/17535069.2012.727545.

Mangin, W. (ed.) (1970) Peasants in Cities: Readings in the Anthropology of Urbanization (Boston: Houghton Mifflin).

Massey, D. (2005) For Space (London: Sage).

McKinsey Global Institute (2010) Lions on the Move: The Progress and Potential of African Economies (Seoul, San Francisco, London, Washington D.C.: McKinsey). http:// www.mckinsey.com/global-themes/middle-east-and-africa/lions-on-the-move (accessed on 1 September 2017).

Melber, H. (ed.) (2016) The Rise of Africa's Middle Class: Myths, Realities and Critical Engagements, Nordiska Afrikainstitutet, (London, Uppsala: Zed Books).

Mercer, C. (2014) 'Middle Class Construction. Domestic Architecture, Aesthetics and Anxieties in Tanzania', Journal of Modern African Studies, 52(2), pp. 227-250, DOI: 10.1017/Soo22278X14000068.

Mwaniki, P. (2014) 'How to Spot a Nairobian', Daily Nation, 3 October.

Ncube, M. and C.L. Lufumpa (2015) The Emerging Middle Class in Africa (London and New York: Routledge).

Neubert, D. (2005) 'Kulturelle Differenz und soziale Strukturierung in Afrika', in R. Kössler, D. Kumitz and U. Schultz (eds.) Gesellschaftstheorie und Provokationen der Moderne. Gerhard Hauck zum 65. Geburtstag, Peripherie. Sonderband, No. 1 (Münster: Westfälisches Dampfboot), pp. 178-192.

Neubert, D. and F. Stoll (2018) 'The Narrative of "the African Middle Class" and its Conceptual Limitations', in L. Kroeker, D. O'Kane and T. Scharrer (eds.) Middle Classes in Africa. Changing Lives and Conceptual Challenges (Basingstoke and New York: Palgrave Macmillan), pp. 57-79.

Neubert, D. and F. Stoll (2015) 'Socio-Cultural Diversity of the African Middle Class: The Case of Urban Kenya', Academy Reflects, No. 1, IAS Working Paper Series, No. 14 (Bayreuth: Institut für Afrika Studien, Universität Bayreuth).

Niechoj, K. (2016) Das christlich engagierte Milieu in Eldoret, Kenia, http://www .bayreuth-academy.uni-bayreuth.de/resources/Masterarbeit_Niechoj.pdf (accessed 1 September 2017). 
Oxfam (2009) Urban Poverty and Vulnerability in Kenya. Background Analysis for the Preparation of an Oxfam GB Urban Programme Focused on Nairobi, https://urban healthupdates.files.wordpress.com/2009/og/urban_poverty_and_vulnerability_in _kenya1.pdf (accessed on 1 September 2017).

Otte, G. and J. Rössel, J. (eds.) (2012) Lebensstilforschung, Kölner Zeitschrift für Soziologie und Sozialpsychologie, Sonderheft, $5^{1}$ (Wiesbaden: Springer).

Parnell, S. and E. Pieterse (2016) 'Translational Global Praxis: Rethinking Methods and Modes of African Urban Research' International Journal of Urban \& Regional Research 4o(1), pp. 236-246, DOI: 10.1111/1468-2427.12278.

Rebstein, B. and B. Schnettler (2014) 'Sozialstrukturanalyse "feiner Körnung" oder subjektzentrierte Lebensweltanalyse? Ungleichheitsbezogene und wissenssoziologische Ansätze der Milieuanalyse', in P. Isenböck, L. Nell and J. Renn (eds.) Die Form des Milieus. Zum Verhältnis von gesellschaftlicher Differenzierung und Formen der Vergemeinschaftung, Zeitschrift für theoretische Soziologie, Sonderband, 1, pp. 46-68.

Ricci, L. (2016) 'Reinterpreting Sub-Saharan Cities through the Concept of Adaptive Capacity: An Analysis of Autonomous Adaptation in Response to Environmental Changes in Peri-Urban Areas', SpringerBriefs in Environment, Security, Development and Peace, 26 (Cham, Heidelberg, New York, Dordrecht, London: Springer).

Robinson, J. (2006) Ordinary Cities. Between Modernity and Development: Questioning Cities (London and New York: Routledge).

Schmid, C. (2005) Stadt, Raum und Gesellschaft. Henri Lefebvre und die Theorie der Produktion des Raumes (Stuttgart: Franz Steiner).

Schulze, G. (1993) Die Erlebnisgesellschaft. Kultursoziologie der Gegenwart (Frankfurt am Main: Campus Verlag).

Sinus (2015) Informationen zu den Sinus-Milieus 2015 (Heidelberg: SINUS) https://www .sinus-institut.de/fileadmin/user_data/sinus-institut/Downloadcenter/Informa tionen_zu_den_Sinus-Milieus.pdf (accessed on 1 September 2017).

Spronk, R. (2012) Ambiguous Pleasures. Sexuality and Middle Class Self-Perceptions in Nairobi (New York: Berghahn Books).

Spronk, R. (2009) 'Sex, Sexuality and Negotiating Africanness in Nairobi', Africa 79(04), pp. 500-519, DOI: 10.3366/Eooo1972009001041.

Stoll, F. (2018) 'How to be middle class in Nairobi: Lifestyles of middle-income milieus and their relation to Nairobi's city structure' in A. Ahmad, D. Nicoue, J. Riess, J. Sarre and F. Stoll, Living in African Cities: Urban Spaces, Lifestyles and Social Practices in Everyday Life, Bigsas Works, Bayreuth African Studies Working Paper Series.

Stoll, F. (2017) 'Middle Classes', in G. Antonelli and B. Rehbein, Inequality in Economics and Sociology: New Perspectives (London and New York: Routledge), pp. 81-97.

Stoll, F. (2016) 'Lebensweisen von Mittelschicht-Milieus in Nairobi: Eine Analyse mit Randall Collins' Interaction Ritual Chains', in A. Daniel, S. Müller, F. Stoll and R. 
Öhlschläger (eds.) Mittelklassen, Mittelschichten oder Milieus in Afrika? Gesellschaften im Wandel, Politik und Gesellschaft in Afrika, Vol. 2 (Baden-Baden: Nomos), pp. $195^{-216 .}$

UN-Habitat (2016) Urban Data (Nairobi: UN-Habitat), http://urbandata.unhabitat.org (accessed on 1 September 2017).

UN-Habitat (2013) The State of Urban Youth 2012/2013: Youth in the Prosperity of Cities, (Nairobi: UN-Habitat) https://unhabitat.org/books/the-state-of-urban-youth -20122013-youth-in-the-prosperity-of-cities/ (accessed on 1 September 2017).

Vester, M., H. Geiling, T. Hermann, D. Müller and P. von Oertzen (2001) Soziale Milieus im gesellschaftlichen Strukturwandel. Zwischen Integration und Ausgrenzung, Suhrkamp Taschenbuch Wissenschaft, No. 1312 (Frankfurt am Main: Suhrkamp).

Werthmann, K. (2014) 'Sind Städte in Afrika „unkennbar“? Ethnologische Stadtforschung in Afrika', in Zeitschrift für Ethnologie, 139 (2), pp. 159-178. 